\title{
The effect of different irrigation solutions on fracture healing in a rat femur fracture model
}

\author{
Hakan Özbay, MD ${ }^{1,2} \mathbb{D}$, Serdar Yüksel, MD²D, M. Akif Güleç, $\mathrm{MD}^{2} \mathbb{D}$, Tolgahan Atçı, $\mathrm{MD}^{3} \mathbb{D}$, \\ B. Onur Küçükyıldıım, $\mathrm{MD}^{4} \odot$, Tuğçe Çay, $\mathrm{MD}^{5}$ (]) \\ ${ }^{1}$ Department of Orthopedics and Traumatology, Ağrı State Hospital, Ağrı, Turkey \\ ${ }^{2}$ Department of Orthopedics and Traumatology, University of Health Science, Bağcılar Training and Research Hospital, Istanbul, Turkey \\ ${ }^{3}$ Department of Orthopedics and Traumatology, Sorgun State Hospital, Yozgat, Turkey \\ ${ }^{4}$ Department of Mechanical Engineering, Yıldız Technical University, Istanbul, Turkey \\ ${ }^{5}$ Department of Pathology, University of Health Science, Bağcılar Training and Research Hospital, Istanbul, Turkey
}

Open fractures, which may be defined as incomplete amputations, are among orthopedic surgical emergencies. Open fracture management consists of evaluation of the patient, classification of the fracture, antibiotic treatment, debridement and irrigation, fracture stabilization, wound management and supportive procedures. ${ }^{[1]}$ Infection, nonunion, sepsis, osteomyelitis and amputation are some of the complications that can emerge in case of inappropriate management of open fractures. ${ }^{[2]}$

Adequate debridement and irrigation are the most important interventions to diminish risks and avoid complications. Open fracture irrigation with normal saline or various irrigatives for optimizing wound and fracture healing has a vital role to diminish

Received: June 19, 2020

Accepted: October 01, 2020

Published online: January 06, 2021

Correspondence: Hakan Özbay, MD. Ağrı Devlet Hastanesi Ortopedi ve Travmatoloji Kliniği, 04200 Ağrı, Türkiye.

E-mail: ozbayhakan@hotmail.com

Doi: $10.5606 /$ ehc. 2021.77358

Citation: Özbay $H$, Yüksel S, Güleç MA, Atçı T, Küçükyıldırım $B O$, Çay T. The effect of different irrigation solutions on fracture healing in a rat femur fracture model. Jt Dis Relat Surg 2021;32(1):144-151

(C2021 All right reserved by the Turkish Joint Diseases Foundation

This is an open access article under the terms of the Creative Commons Attribution-NonCommercial License, which permits use, distribution and reproduction in any medium, provided the original work is properly cited and is not used for commercial purposes (http://creativecommons.org/licenses/by-nc/4.0/).

\section{ABSTRACT}

Objectives: This study aims to evaluate and compare radiological, biomechanical, histopathological, histomorphometric and immunohistochemical effects of povidone iodine (PVP-I), hydrogen peroxide (HPO) and chlorhexidine gluconate (CHG) on fracture healing in their minimum cytotoxic and most efficient concentrations.

Materials and methods: This experimental animal study, conducted between April 2018 and January 2019, included 48 male Sprague Dawley ${ }^{\circledR}$ rats (weighing 356 g; aging 9 weeks) which were randomly divided into four groups: control (saline), HPO, PVP-I and CHG. Rat model of femoral fracture was established and intramedullary fixation was applied. Solutions were applied to fracture region in determined concentration and time, and all subjects were sacrificed on Day 28. Extracted femurs were investigated radiologically by micro-computed tomography. Then, all groups were divided into two random groups to be evaluated biomechanically, histopathologically, histomorphometrically and immunohistochemically.

Results: In histopathological evaluation, inflammation score of CHG group was significantly lower than other groups, and inflammation score of PVP-I group was significantly lower than control and HPO groups $(\mathrm{p}<0.05)$. Biomechanically, flexural strength (obend) (megapascal) values of $\mathrm{CHG}$ and control groups showed similar results, but there was no significant difference between all groups $(\mathrm{p}>0.05)$. In immunohistochemical localization of bone morphogenic protein (BMP)-4, osteoblast and chondroblast histoscores (H-scores) of HPO group were significantly lower than other groups, and chondroblast $\mathrm{H}$-score in CHG group was lower than control and PVP-I groups $(\mathrm{p}<0.05)$. In immunohistochemical localization of BMP-7, osteoblast $\mathrm{H}$-score was significantly higher in $\mathrm{CHG}$ group than other groups $(\mathrm{p}<0.05)$.

Conclusion: We determined that CHG $0.05 \%$ solution had no negative effect on the fourth week of fracture healing histopathologically, immunohistochemically and biomechanically, and is an alternative irrigative to normal saline.

Keywords: Antiseptic agent, femur, fracture healing, infection, rats. 
bacterial load. Despite this significance, there is no consensus in the literature on the amount, additives or form of irrigation.

Antiseptics and antibiotics have been used as adjuvants in irrigation solutions and there are many studies about the effect of these solutions on soft tissue toxicity and bacterial load, while there is limited number of studies about their effect on fracture healing. Many methods and devices were studied and used to avoid orthopedic infections in open fracture treatment, while changing the solution in irrigation phase is easily applicable, accessible and cost-effective. ${ }^{[3,4]}$

In this study, we hypothesized that chlorhexidine gluconate (CHG) $0.05 \%$ solution is an alternative irrigative in open fracture treatment, due to its antiseptic features without affecting fracture healing. Therefore, in this study, we aimed to evaluate and compare radiological, biomechanical, histopathological, histomorphometric and immunohistochemical effects of povidone iodine (PVP-I), hydrogen peroxide (HPO) and CHG on fracture healing in their minimum cytotoxic and most efficient concentrations.

\section{MATERIALS AND METHODS}

This experimental animal study was conducted at University of Health Sciences Istanbul Bağcılar Training and Research Hospital between April 2018 and January 2019. The study included 48 male Sprague Dawley ${ }^{\circledR}$ rats (weighing 356 g; aging 9 weeks). The study was approved by the University of Health Sciences Istanbul Bağcılar Training and Research Hospital Ethics Committee (Approval Number: 2018-11) and achieved according to ETS-123 and European Convention for the Protection of Vertebrate Animals Used for Experimental and Other Scientific Purposes. ${ }^{[5]}$ In this experimental study, all animals were subjected to all interventions according to the Guide for the Care and Use of Laboratory Animals and Animal Experiments Ethics Committee Approval Report.

Exclusion criteria were inconvenient implant position, fixation failure, infection, weight loss of more than 20\%, another fracture line, insufficient nutrition of rats and failure to respond to stimuli. ${ }^{[6]}$

The rats were anesthetized by intraperitoneal ketamine $80 \mathrm{mg} / \mathrm{kg}$ (Ketalar ${ }^{\circledR}$, Pfizer, Berlin, Germany) and xylazine $5 \mathrm{mg} / \mathrm{kg}$ (Rompun ${ }^{\circledast}$, Bayer, Berlin, Germany). One single dose of gentamicin $8 \mathrm{mg} / \mathrm{kg}$ $\left(\right.$ Genta ${ }^{\circledR}$, I.E. Ulagay, Istanbul, Türkiye) was injected as antibiotic prophylaxis. After surgical interventions, one dose of subcutaneous carprofen $3 \mathrm{mg} / \mathrm{kg}$ (Rimady ${ }^{\circledR}$, Zoetis, Parsippany, New Jersey, USA) was applied to all animals daily for analgesic medication, for two days. Carprofen $3 \mathrm{mg} / \mathrm{kg}$ (Rimadyl ${ }^{\circledR}$, Zoetis, Parsippany, New Jersey, USA) was injected to animals as analgesic medication after two days, if needed. So, animals were protected against pain or disturbance. Right mid-diaphyseal femur of all rats were explored through anterolateral approach, and osteotomized transversely by micromotor (ConMed Linvatec ${ }^{\circledR}$ Pro-6200 Motor, California, USA); thus, rat femur open fracture model was created (Figure 1).

Fracture region was exposed and irrigated with $100 \mathrm{~mL} 0.9 \%$ saline in the control group $(\mathrm{n}=12)$. HPO $3 \%$ solution was applied to fracture region for $2 \mathrm{~min}$ in HPO group $(n=12)$. Fracture region was irrigated with PVP-I 1\% solution for 2 min in PVP-I group $(n=12)$. CHG $0.05 \%$ solution was used for irrigation for $1 \mathrm{~min}$ in CHG group $(n=12)$. Then, fracture regions of all groups were irrigated with $100 \mathrm{~mL} 0.9 \%$ saline. After irrigation, all fractures were fixed with retrograde Kirschner wires and radiographically confirmed (Figure 2). At the end of the fourth week, all rats were sacrificed with high dose ketamine $\left(\operatorname{Ketalar}^{\circledR}\right.$, Pfizer, Berlin, Germany) and xylazine (Rompun ${ }^{\circledR}$, Bayer, Berlin, Germany). After sacrification, right

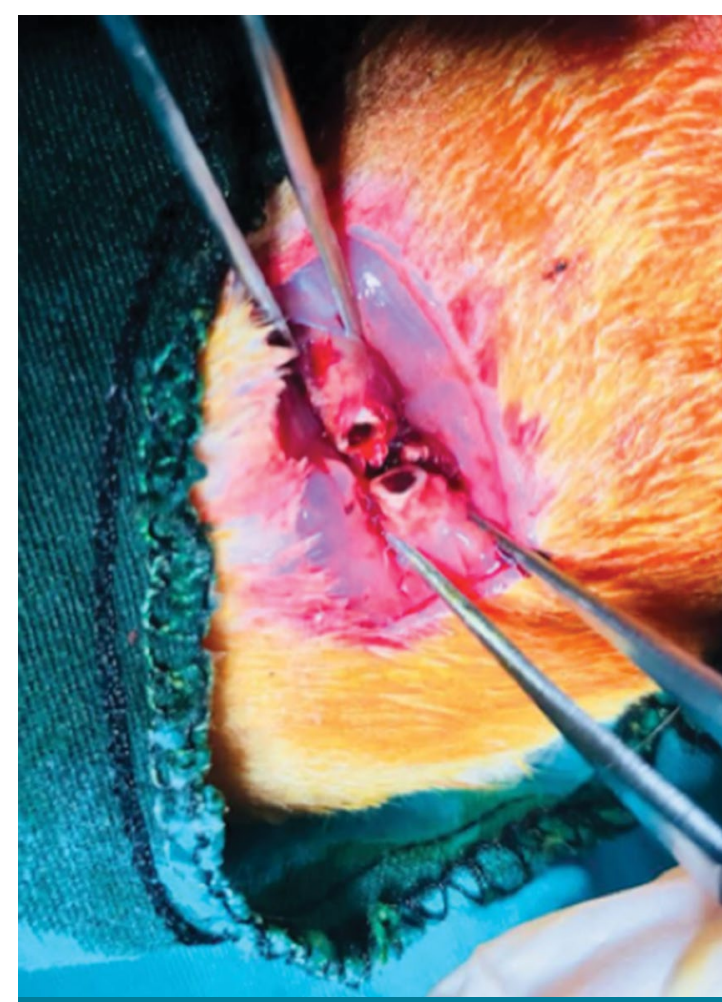

FIGURE 1. Appearance of surgical field after osteotomy. 


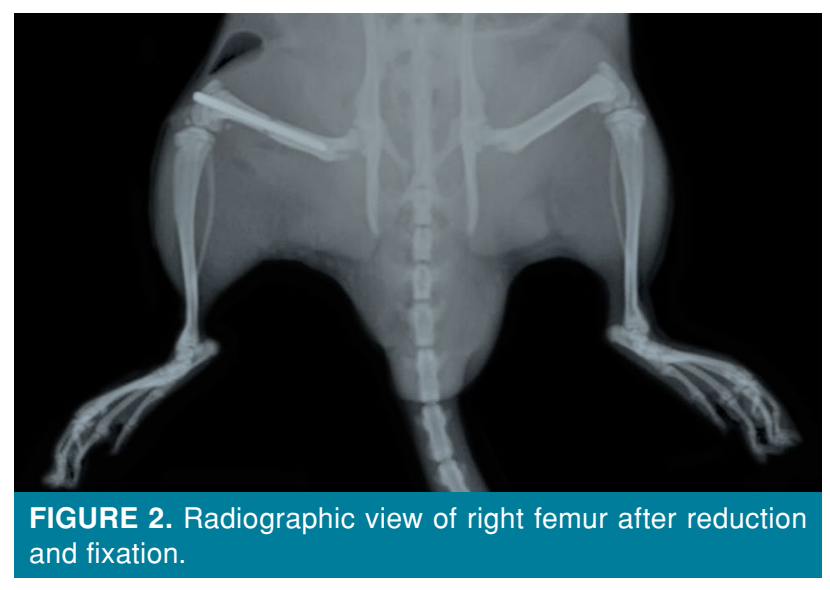

femurs of all rats were extracted, and Kirschner wires were removed. Then, femurs were fixed in formalin for histological, radiological and biomechanical investigations.

All samples were evaluated radiologically with micro-computed tomography (mCT) device (SkyScan ${ }^{\circledR}$, Bruker, Billerica, Massachusetts, USA) for measurement of bone mineral density (BMD, $\mathrm{g} / \mathrm{cm}^{3}$ ) and new callus formation $\left(\mathrm{mm}^{3}\right)$ (Figure 3). After radiological evaluation, each group was divided into two groups randomly in equal numbers for biomechanical and histological evaluation. In biomechanical test, three point bending test was applied with class 1 calibrated universal mechanical

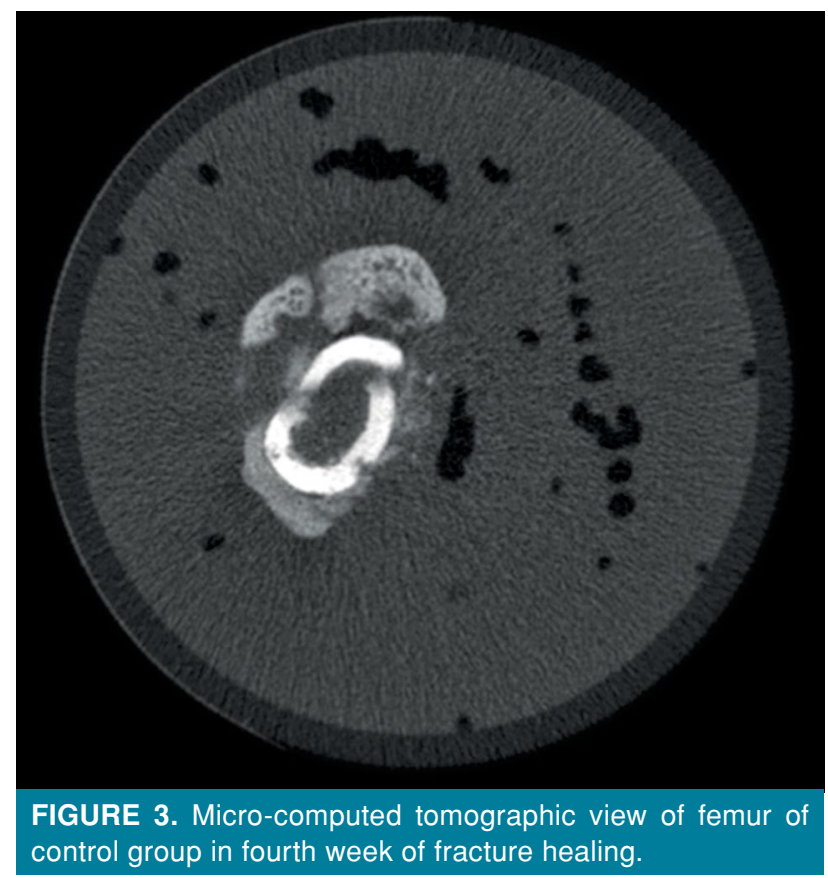

testing device (Alsa Laboratory Devices, Ltd., Istanbul, Turkey). Ultimate bending force $\left(\mathrm{F}_{\max }\right)$ values were measured and flexural strength ( $\left.\sigma_{\text {bend }}\right)$ was calculated by using the following equations (Eq. 1 to 4 ):

$$
\begin{aligned}
& \sigma_{\text {bend }}=\mathrm{Mc} / \mathrm{I} \\
& \mathrm{M}=\mathrm{FL} / 4 \\
& \mathrm{c}=\mathrm{D} / 2 \\
& \mathrm{I}=\pi\left(\mathrm{D}^{4}-\mathrm{d}^{4}\right) / 64
\end{aligned}
$$

Where $\mathrm{M}$ is the maximum bending moment, $\mathrm{L}$ is the distance between supports, $\mathrm{c}$ is the distance to neutral axis, I is the moment of inertia, D is the outer diameter and $\mathrm{d}$ is the inner diameter of the bone. In the name of biomechanical results, $F_{\max }$ values itself are not enough in understanding the strength of bone, because the strength is the force acting to the fracture surface cross-sectional area of the bone. Thus, we take the $\sigma_{\text {bend }}$ values into consideration to understand the effect of healing by looking at strength enhancements.

Six samples of each group were fixed in formalin $10 \%$ for one week and decalcified for three days. After alcohol, acetone, xylene and paraffin processes, samples were dehydrated and embedded in paraffin. They were sliced longitudinally with a 3-4 $\mu \mathrm{m}$ microtome and stained with hematoxylin and eosin and Masson's trichrome and evaluated with the numerical scoring scheme used for histologic evaluation of fracture healing (Table I). ${ }^{[7]}$

\section{TABLE I}

Histological scoring system of fracture healing defined by Huo et al. ${ }^{[12]}$

$\begin{array}{cll}\text { Score } & \text { Assessment of histology } \\ 1 & \text { Fibrous tissue } \\ 2 & \begin{array}{l}\text { Predominant fibrous tissue with minimal cartilage } \\ \text { tissue }\end{array} \\ 3 & \begin{array}{l}\text { Cartilage tissue and fibrous tissue in a uniform } \\ \text { manner }\end{array} \\ 4 & \begin{array}{l}\text { Predominant cartilage tissue with minimal fibrous } \\ \text { tissue }\end{array} \\ 5 & \begin{array}{l}\text { Cartilage tissue } \\ 6\end{array} & \begin{array}{l}\text { Predominant cartilage tissue with minimal immature } \\ \text { bone }\end{array} \\ 7 & \begin{array}{l}\text { Immature bone and cartilage tissue in a uniform } \\ \text { manner }\end{array} \\ 8 & \begin{array}{l}\text { Predominant immature bone with minimal cartilage } \\ \text { tissue }\end{array} \\ 9 & \begin{array}{l}\text { Bone healing with immature bone } \\ 10\end{array} & \text { Bone healing with matured bone }\end{array}$




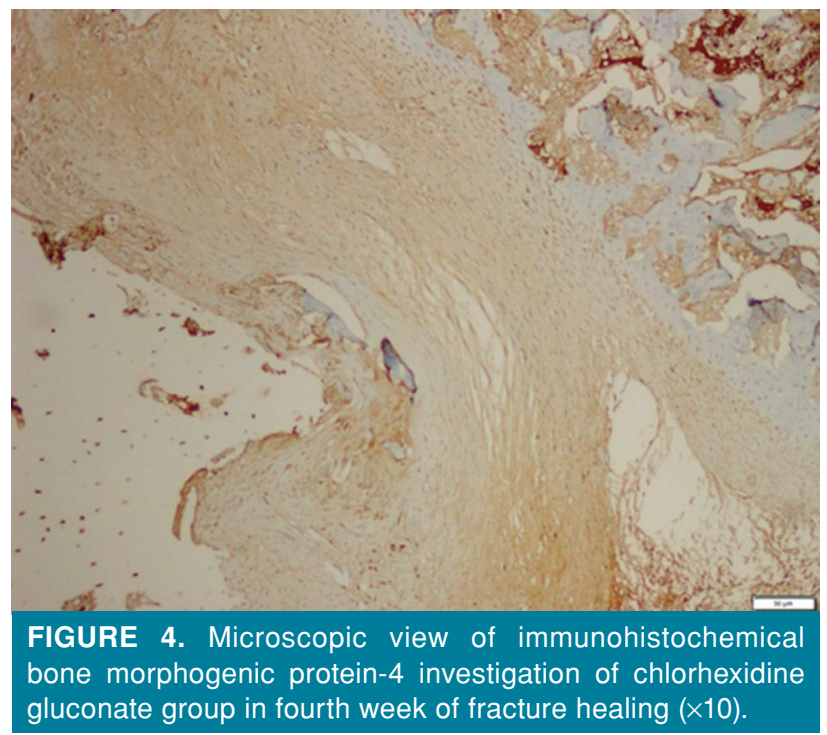

Inflammation scoring was based on lymphocyte infiltration numerated as 0 for no inflammation, 1 for mild inflammation, 2 for moderate inflammation and 3 for severe inflammation.

Slices of 3-4 $\mu \mathrm{m}$ were used for quantitative histomorphometric evaluation of fracture region and two regions were measured. These were cortex area $\left(\mathrm{CtAr}, \mathrm{mm}^{2}\right)$ and total callus area $\left(\mathrm{CAr}, \mathrm{mm}^{2}\right)$ that contain ossifying tissue, cartilage tissue and fibrous callus. CAr/CtAr was measured as \%.

Total callus area was measured as mean $\mathrm{mm}^{2}$ value of fracture region that contains all tissues inside and outside of cortical bone. Cortical area was measured as mean $\mathrm{mm}^{2}$ value of total area that is fulfilled by cortical tissue. ${ }^{[8,9]}$

For immunohistochemical evaluation, positive charged slides were used and sections were waited in $60^{\circ} \mathrm{C}$ oven for $60 \mathrm{~min}$. Samples were stained with DAB (3,3'-Diaminobenzidine) V3 protocol (Ventana BenchMark $^{\circledR}$ XT, V3, Roche Diagnostics, Istanbul, Turkey). After alcohol and xylene, all slides were closed in automatic tissue embedder device (Sakura Tissue-Tek Film ${ }^{\circledR}$ Automated Coverslipper, Sakura Finetek, Torrance, California, USA). Five regions were evaluated by two researchers for positive immune marking of bone morphogenic protein (BMP)-4, BMP-7 and cluster of differentiation (CD) 34 and scored between 0-300 with semiquantitative histoscore (H-score) (Figure 4). ${ }^{[10]}$ H-score is a combined semiquantitative scoring system determined by adding the results of multiplication of the percentage of cells with staining intensity ordinal value (scored from 0 for no signal to 3 for strong signal) with 300 possible values. ${ }^{[1]}$ Staining intensity ordinal values of BMP-4, BMP-7 and CD34 proteins on osteoblasts, chondroblasts and fibroblasts of all groups were evaluated and scored by $\mathrm{H}$-score scoring system. Thus, numerical data were recorded for statistical analysis of immunohistochemical evaluation.

\section{Statistical analysis}

Statistical analysis was performed using the IBM SPSS version 22.0 software (IBM Corp., Armonk, NY, USA). Mean, standard deviation, median, ratio and frequency values were used in descriptive analysis of data. Distribution of variables was analyzed with Kolmogorov-Smirnov test. T test, Kruskal-Wallis and Mann-Whitney $U$ tests were used for analysis of independent quantitative variables. The results were evaluated according to the significance value of $p<0.05$.

\section{RESULTS}

In radiological evaluation, $\mathrm{CAr} / \mathrm{CtAr}(\%)$ values were lower in CHG group, while there was no statistically significant difference between all groups $(\mathrm{p}>0.05)$. BMD $\left(\mathrm{g} / \mathrm{cm}^{3}\right)$ values of PVP-I group were significantly lower than other groups $(\mathrm{p}<0.05)$ with no statistically significant difference between other groups $(\mathrm{p}>0.05)$ (Table II).

In biomechanical evaluation, $\mathrm{F}_{\max }$ Newton $(\mathrm{N})$ values of CHG group were higher than other groups, with no statistically significant difference

\begin{tabular}{|c|c|c|c|c|c|c|c|c|c|}
\hline \multicolumn{10}{|c|}{ TABLE II } \\
\hline & \multicolumn{2}{|c|}{ Control } & \multicolumn{2}{|c|}{ PVP-I } & \multicolumn{2}{|c|}{$\mathrm{CHG}$} & \multicolumn{2}{|c|}{$\mathrm{HPO}$} & \multirow[b]{2}{*}{$p^{*}$} \\
\hline & Mean \pm SD & Median & Mean $\pm S D$ & Median & Mean \pm SD & Median & Mean \pm SD & Median & \\
\hline Bone mineral density & $3.7 \pm 0.8 \dagger$ & 3.7 & $2.5 \pm 0.6$ & 2.5 & $3.5 \pm 0.6 \dagger$ & 3.5 & $3.4 \pm 0.6 \dagger$ & 3.5 & 0.003 \\
\hline Callus volume & $79.9 \pm 26.0$ & 75.5 & $92.8 \pm 46.9$ & 81.3 & $86.0 \pm 18.6$ & 88.1 & $75.8 \pm 27.8$ & 69.8 & 0.466 \\
\hline Cortex volume & $82.4 \pm 22.4$ & 87.1 & $76.3 \pm 22.6$ & 81.6 & $79.0 \pm 14.9$ & 76.9 & $81.2 \pm 11.1$ & 82.8 & 0.832 \\
\hline Cortex/callus volume & $1.0 \pm 0.4$ & 0.9 & $1.1 \pm 0.5$ & 1.1 & $0.9 \pm 0.2$ & 1.0 & $1.2 \pm 0.4$ & 1.2 & 0.353 \\
\hline
\end{tabular}




\begin{tabular}{|c|c|c|c|c|c|c|c|c|c|}
\hline \multicolumn{10}{|c|}{$\begin{array}{l}\text { TABLE III } \\
\text { iomechanical parameters between groups }\end{array}$} \\
\hline & \multicolumn{2}{|c|}{ Control } & \multicolumn{2}{|c|}{ PVP-I } & \multicolumn{2}{|c|}{$\mathrm{CHG}$} & \multicolumn{2}{|c|}{ HPO } & \multirow[b]{2}{*}{$p^{*}$} \\
\hline & Mean $\pm S D$ & Median & Mean $\pm S D$ & Median & Mean $\pm S D$ & Median & Mean $\pm S D$ & Median & \\
\hline $\mathrm{F}_{\max }(\mathrm{N})$ & $64.5 \pm 27.2$ & 58.9 & $56.0 \pm 29.6$ & 63.2 & $78.8 \pm 31.7$ & 71.8 & $60.0 \pm 56.8$ & 44.9 & 0.435 \\
\hline$\sigma_{\text {bend }}(\mathrm{MPa})$ & $81.8 \pm 31.1$ & 69.9 & $60.1 \pm 17.8$ & 60.1 & $71.4 \pm 6.4$ & 72.3 & $65.2 \pm 16.5$ & 61.8 & 0.324 \\
\hline
\end{tabular}

\begin{tabular}{|c|c|c|c|c|c|c|c|c|c|}
\hline & Statistical c & mparisor & $\begin{array}{l}\text { TABL } \\
\text { of histopath }\end{array}$ & $\begin{array}{l}\text { IV } \\
\text { logical fin }\end{array}$ & dings betwee & n groups & & & \\
\hline & Cont & & PVF & & $\mathrm{CH}$ & & $\mathrm{HP}$ & & \\
\hline & Mean $\pm S D$ & Median & Mean $\pm S D$ & Median & Mean $\pm S D$ & Median & Mean $\pm S D$ & Median & $p^{*}$ \\
\hline Fracture Healing Score & $4.7 \pm 1.0$ & 5.0 & $4.3 \pm 1.2$ & 4.5 & $5.2 \pm 0.8$ & 5.0 & $3.3 \pm 1.5$ & 3.0 & 0.124 \\
\hline Inflammation Score & $1.7 \pm 0.5 \dagger \ddagger$ & 2.0 & $1.0 \pm 0.6 \ddagger$ & 1.0 & $0.2 \pm 0.4$ & 0.0 & $2.0 \pm 0.8 † \ddagger$ & 2.0 & 0.003 \\
\hline
\end{tabular}

between all groups $(\mathrm{p}>0.05)$. $\sigma_{\text {bend }}$ (megapascal) values of CHG and control groups were similar and higher than other groups, with no statistically significant difference between all groups $(p>0.05)$ (Table III).

In histopathological evaluation, higher histological fracture healing scores were detected in control and CHG groups, with no statistically significant difference between all four groups ( $>0.05)$. Inflammation scores of CHG group were significantly lower than other groups $(\mathrm{p}<0.05)$ (Table IV).

In histomorphometric evaluation, CAr/CtAr \% values of HPO group were significantly lower than other groups $(\mathrm{p}<0.05)$. In PVP-I group, $\mathrm{CAr} / \mathrm{CtAr} \%$ values were significantly lower than control and CHG groups $(\mathrm{p}<0.05)$. CAr/CtAr \% values of CHG group were significantly lower than control group $(\mathrm{p}<0.05)$.

In $\mathrm{H}$-score values of BMP-4 evaluation, chondroblast $\mathrm{H}$-scores of $\mathrm{HPO}$ and $\mathrm{CHG}$ groups were significantly lower than control and PVP-I groups $(p<0.05)$, with no statistically significant difference between CHG and HPO groups ( $p>0.05$ ). H-scores for osteoblasts in HPO group were significantly lower than control and CHG groups ( $<<0.05)$, and there was no statistically significant difference between control, PVP-I and CHG groups ( $p>0.05$ ). When we evaluated BMP-4 expression on fibroblast cells, there was no statistically significant difference between $\mathrm{H}$-scores of CHG, PVP-I, HPO and control groups ( $p>0.05$ ).
When we evaluated H-scores of BMP-7 localization and immunoreactivity, fibroblast $\mathrm{H}$-scores in $\mathrm{CHG}$ group were significantly lower than other groups $(\mathrm{p}<0.05)$. Fibroblast $\mathrm{H}$-scores in PVP-I group were significantly lower than control group $(\mathrm{p}<0.05)$. There was no statistically significant difference between groups in respect to chondroblast $\mathrm{H}$-scores $(\mathrm{p}>0.05)$. Osteoblast H-scores in $\mathrm{CHG}$ group were significantly higher than other groups $(\mathrm{p}<0.05)$, with no statistically significant difference between PVP-I and control groups ( $p>0.05)$.

There was no statistically significant difference between all groups in respect to CD34 H-scores $(\mathrm{p}>0.05)$.

\section{DISCUSSION}

Prevention of orthopedic infections due to open fractures or surgical procedures is of paramount importance. Because of increased resistance to antibiotics and complication rates after orthopedic surgeries, appropriate selection of intraoperative irrigation solutions may be an effective effort to reduce infection rates. Also, an antiseptic solution used in open fracture management as an irrigative could diminish complication rates related to infection. ${ }^{[12,13]}$

Chlorhexidine gluconate is an antiseptic that uses mechanical features of a liquid removing bacteria and combines antimicrobial features without affecting host cells. It has a broad spectrum for gram-positive and gram-negative bacteria, fungi and prokaryotic cell membrane with low toxicity to mammalian tissue. ${ }^{[14]}$ 
Interestingly, $\mathrm{CHG}$, which has a wide range of use in modern practice with low toxicity and with effective antiseptic activity, has not been investigated as an irrigation solution in clinical or animal experimental open fracture model. Despite this lack of evidence, some surgeons advise the use of this solution in surgical field instead of normal saline..$^{[5]}$

One of the advantages of CHG is that there is no resistance to its antimicrobial effect. Also, it does not lose its effect in body fluids like blood, unlike other antiseptic solutions. Moreover, it distributes slowly from solid or soft tissues and shows its antimicrobial effect in an appropriate time period. ${ }^{[15]}$

Different types of animals including rabbits, dogs, and sheep, etc. are preferred for use in studies. ${ }^{[16]}$ We preferred Sprague Dawley ${ }^{\circledR}$ rats because of standardization of fracture model, repeatability, accessibility to antibodies in study and cost. Experimental fracture models can be created by open (osteotomy) and closed (blunt trauma) techniques. We chose open fracture model to serve the purpose of our study, while blunt trauma may cause high death ratios, failure to standardize fracture type and fragment number and soft tissue damage. ${ }^{[17]}$

Combining biomechanical and radiological results with quantitative histological results is extremely important for the objectivity of the study. Gerstenfeld et al. ${ }^{[18]}$ determined some parameters of bone healing on histomorphometric investigation of fracture healing. In our study, CAr/CtAr \% value of these parameters was chosen to correlate with $\mathrm{mCT}$ data and compared with radiological results. CHG and control groups showed similar and parallel radiological and histomorphometric results, and there was no statistically significant difference between other groups. Siwicka et al. ${ }^{[19]}$ showed that different immunohistochemical receptor markers have roles in different weeks of bone healing. Also, Haque et al. ${ }^{[20]}$ indicated bone morphogenic factor, signal molecules in fibroblast and osteoblast cells in fracture healing sites and used semi-quantitative scoring system. In the same study, they suggested semi-quantitative or quantitative evaluation for statistical purposes. Gerstenfeld et al. ${ }^{[21]}$ stated in their study that expression of fracture healing markers changes by stage of fracture healing. Immunohistochemical markers evaluated in our study had important roles in fourth week of fracture healing. In our study, we used BMP-4, BMP-7 and CD34 as immunohistochemical markers of fracture healing in the fourth week of bone healing and evaluated semi-quantitatively between 0 and $300 \mathrm{H}$-scores for objective results. ${ }^{[22]}$
Ramchandani and Weber ${ }^{[23]}$ showed that low concentration PVP-I increases mesenchymal stem cell differentiation and new bone formation by increasing BMP-2 and osteopontin expression. In our study, PVP-I $1 \%$ had no negative effect on fracture healing in histopathological evaluation. Also, we found no negative effect on osteoblast BMP-4 and BMP-7 expression in immunohistochemical evaluation. However, we showed the negative effect of PVP-I $1 \%$ on BMD in the fourth week of bone healing.

Taylor et al. ${ }^{[24]}$ stated that CHG $0.05 \%$ eliminates $99.8 \%$ of contaminating bacteria within $1 \mathrm{~min}$ in a tissue model when used in lavage, which is the rationale behind different exposure times between these three solutions. Moreover, it has no negative effect on cartilage tissue without osteoarthritis. In a study, it was thought that a high concentration of $\mathrm{CHG}$ is toxic to human cartilage in open or arthroscopic surgery, in undefined contact times. However, their effect on human osteoblast is still not clear. ${ }^{[25]}$ In a recent study, Vörös et al. ${ }^{[26]}$ showed that CHG has a toxic effect on osteoblasts, in vitro. In our study, we showed that CHG $0.05 \%$ has no negative effect on osteoblasts, immunohistochemically. In a contaminated open fracture model, saline and CHG solutions were compared, and usage of CHG alone was not suggested while lavage with saline after CHG irrigation was recommended. ${ }^{[27]}$ In our study, we irrigated the osteotomy field with saline after $1 \mathrm{~min}$ of CHG $0.05 \%$ usage. Liu et al. ${ }^{[13]}$ showed the toxic effect of $\mathrm{CHG}$ on osteoblast, fibroblast and myoblast, in vitro, and they stated that new in vivo studies are needed on this topic. In our study, we showed that CHG $0.05 \%$ had no negative effect on BMP-4 and BMP-7 expression of osteoblast, fibroblast and chondroblast while we detected lower $\mathrm{H}$-scores of BMP-7 expression of fibroblast.

In a recent study, Shiels et al. ${ }^{[28]}$ used CHG releasing implant coating on intramedullary nail as fixation device and showed that it reduces infection in rat fracture model. However, they did not study its effect on fracture healing. In our study, we found that CHG $0.05 \%$ solution did not have any negative effect on fracture healing, histopathologically. Also, inflammation score of CHG group was lower than other groups. In several studies that compared the effect of different antiseptic solutions on bacterial load and soft tissues, CHG showed similar results with normal saline and also superiority to other antiseptics. ${ }^{[29]}$ In our study, similar results were detected in CHG and control groups in the fourth week of fracture healing. CHG group showed superior results to other antiseptic agents radiologically, 
histomorphometrically and biomechanically; besides, it showed no negative effect on fracture healing. In immunohistochemical evaluation during which we investigated BMP-4, BMP-7 and CD34 immunoreactivity on osteoblast, fibroblast and chondroblast in the fourth week of fracture healing, we found superior results in CHG group than PVP-I and HPO groups and similar results with control group.

Husodo et al. ${ }^{[30]}$ compared the histomorphometric effects of PVP-I and HPO on fracture healing in a rat fracture model and suggested the use of PVP-I $1 \%$ as an irrigative in fracture surgery. To our knowledge, ours is the first and only original study evaluating CHG, PVP-I and HPO solutions radiologically, biomechanically, histopathologically and immunohistochemically ${ }^{[31]}$ with such different parameters.

Our study has some limitations. We did not investigate different fracture types and different weeks of fracture healing due to ethical concerns caused by the increased number of rats and loss of standardization. Furthermore, because of the limited number of rats, we did not evaluate different ratios and contact times of solutions.

In conclusion, we recommend the usage of CHG $0.05 \%$ solution in fracture surgery and open fracture treatment as an irrigative because of its antiseptic features that do not affect fracture healing, while further comprehensive studies are needed on this topic. We believe that usage of CHG $0.05 \%$ as an irrigation solution is a simple, accessible and applicable way to diminish the complications of orthopedic infections.

\section{Acknowledgements}

We would like to thank Bagcilar Training and Research Hospital Experimental Research and Skill Development Center. We would also like to thank Yildiz Technical University's Advanced Materials Research Group for their contributions during the course of the study.

\section{Declaration of conflicting interests}

The authors declared no conflicts of interest with respect to the authorship and/or publication of this article.

\section{Funding}

The authors received no financial support for the research and/or authorship of this article.

\section{REFERENCES}

1. Petrisor B, Sun X, Bhandari M, Guyatt G, Jeray KJ, Sprague $S$, et al. Fluid lavage of open wounds (FLOW): a multicenter, blinded, factorial pilot trial comparing alternative irrigating solutions and pressures in patients with open fractures. J Trauma 2011;71:596-606.
2. Canbeyli İD, Kabalcı M, Çırpar M, Tiryaki M, Oktaş B. Mesenchymal stem cells have significant anti-infective effect on methicillin-resistant Staphylococcus epidermidis vascular graft infections. Eklem Hastalik Cerrahisi 2019;30:201-11.

3. Timsit JF, Schwebel C, Bouadma L, Geffroy A, GarrousteOrgeas M, Pease S, et al. Chlorhexidine-impregnated sponges and less frequent dressing changes for prevention of catheter-related infections in critically ill adults: a randomized controlled trial. JAMA 2009;301:1231-41.

4. Hirsch T, Seipp HM, Jacobsen F, Goertz O, Steinau HU, Steinstraesser L. Antiseptics in surgery. Eplasty. 2010;10:e39.

5. de Vries RBM, Hooijmans CR, Langendam MW, van Luijk J, Leenaars M, Hoitinga MR, et al. A protocol format for the preparation, registration and publication of systematic reviews of animal intervention studies. Evid Based Preclin Med 2015;2:1-9.

6. An YH, Friedman RJ, editors. Animal models in Orthopedic Research. 1st ed. New York: CRC Press; 1999.

7. Huo MH, Troiano NW, Pelker RR, Gundberg CM, Friedlaender GE. The influence of ibuprofen on fracture repair: biomechanical, biochemical, histologic, and histomorphometric parameters in rats. J Orthop Res 1991;9:383-90.

8. Recker RR, Kimmel DB, Dempster D, Weinstein RS, Wronski TJ, Burr DB. Issues in modern bone histomorphometry. Bone 2011;49:955-64.

9. Dempster DW, Compston JE, Drezner MK, Glorieux FH, Kanis JA, Malluche H, et al. Standardized nomenclature, symbols, and units for bone histomorphometry: a 2012 update of the report of the ASBMR Histomorphometry Nomenclature Committee. J Bone Miner Res 2013;28:2-17.

10. Karipcin FS, Ensari TA, Kayisli UA, Guzel E, Kallen CB, Seli E. The mRNA-binding protein HuR is regulated in the menstrual cycle and repressed in ectopic endometrium. Reprod Sci 2011;18:145-55.

11. Fedchenko N, Reifenrath J. Different approaches for interpretation and reporting of immunohistochemistry analysis results in the bone tissue - a review. Diagn Pathol 2014;9:221.

12. van Meurs SJ, Gawlitta D, Heemstra KA, Poolman RW, Vogely HC, Kruyt MC. Selection of an optimal antiseptic solution for intraoperative irrigation: an in vitro study. J Bone Joint Surg [Am] 2014;96:285-91.

13. Liu JX, Werner J, Kirsch T, Zuckerman JD, Virk MS. Cytotoxicity evaluation of chlorhexidine gluconate on human fibroblasts, myoblasts, and osteoblasts. J Bone Jt Infect 2018;3:165-72.

14. Douw CM, Bulstra SK, Vandenbroucke J, Geesink RG, Vermeulen A. Clinical and pathological changes in the knee after accidental chlorhexidine irrigation during arthroscopy. Case reports and review of the literature. J Bone Joint Surg [Br] 1998;80:437-40.

15. Berwick JE, Lessin ME. Effects of a chlorhexidine gluconate oral rinse on the incidence of alveolar osteitis in mandibular third molar surgery. J Oral Maxillofac Surg 1990;48:444-8.

16. Manigrasso MB, O'Connor JP. Characterization of a closed femur fracture model in mice. J Orthop Trauma 2004;18:687-95.

17. Aurégan JC, Coyle RM, Danoff JR, Burky RE, Akelina Y, Rosenwasser MP. The rat model of femur fracture for bone and mineral research: An improved description of expected 
comminution, quantity of soft callus and incidence of complications. Bone Joint Res 2013;2:149-54.

18. Gerstenfeld LC, Wronski TJ, Hollinger JO, Einhorn TA. Application of histomorphometric methods to the study of bone repair. J Bone Miner Res 2005;20:1715-22.

19. Siwicka KA, Kitoh H, Kawasumi M, Ishiguro N. Spatial and temporal distribution of growth factors receptors in the callus: implications for improvement of distraction osteogenesis. Nagoya J Med Sci 2011;73:117-27.

20. Haque T, Mandu-Hrit M, Rauch F, Lauzier D, Tabrizian M, Hamdy RC. Immunohistochemical localization of bone morphogenetic protein-signaling Smads during long-bone distraction osteogenesis. J Histochem Cytochem 2006;54:407-15.

21. Gerstenfeld LC, Cullinane DM, Barnes GL, Graves DT, Einhorn TA. Fracture healing as a post-natal developmental process: molecular, spatial, and temporal aspects of its regulation. J Cell Biochem 2003;88:873-84.

22. McCarty KS Jr, Miller LS, Cox EB, Konrath J, McCarty KS Sr. Estrogen receptor analyses. Correlation of biochemical and immunohistochemical methods using monoclonal antireceptor antibodies. Arch Pathol Lab Med 1985;109:716-21.

23. Ramchandani D, Weber GF. Interactions between osteopontin and vascular endothelial growth factor: Implications for skeletal disorders. Bone 2015;81:7-15.
24. Taylor GJ, Leeming JP, Bannister GC. Effect of antiseptics, ultraviolet light and lavage on airborne bacteria in a model wound. J Bone Joint Surg [Br] 1993;75:724-30.

25. Best AJ, Nixon MF, Taylor GJ. Brief exposure of $0.05 \%$ chlorhexidine does not impair non-osteoarthritic human cartilage metabolism. J Hosp Infect 2007;67:67-71.

26. Vörös P, Dobrindt O, Perka C, Windisch C, Matziolis G, Röhner E. Human osteoblast damage after antiseptic treatment. Int Orthop 2014;38:177-82.

27. Penn-Barwell JG, Murray CK, Wenke JC. Comparison of the antimicrobial effect of chlorhexidine and saline for irrigating a contaminated open fracture model. J Orthop Trauma 2012;26:728-32.

28. Shiels SM, Bouchard M, Wang H, Wenke JC. Chlorhexidinereleasing implant coating on intramedullary nail reduces infection in a rat model. Eur Cell Mater 2018;35:178-94.

29. Darouiche RO, Wall MJ Jr, Itani KM, Otterson MF, Webb $\mathrm{AL}$, Carrick MM, et al. Chlorhexidine-alcohol versus povidone-iodine for surgical-site antisepsis. N Engl J Med 2010;362:18-26.

30. Husodo K, Kamal AF, Yusuf AA. Effect of povidone iodine and hydrogen peroxide on fracture healing: a histomorphometric study on rats. J Orthop Surg (Hong Kong) 2016;24:245-9.

31. Atik OŞ. What are the expectations of an editor from a scientific article? Jt Dis Relat Surg 2020;31:597-8. 